\title{
INCARCERATION AS A RESULT OF THE PLAY OF INTERESTS IN THE POLISH JUDICIAL SYSTEM
}

\section{Bartosz Mika}

University of Gdańsk, Poland

Email: bartosz.mika@ug.edu.pl

\section{Arkadiusz Peisert}

University of Gdańsk, Poland

Email: arkadiusz.peisert@gmail.com

Abstract: The main aim of this article is to show one of the social trap of the Polish justice system. Using Mertonian category of 'unforeseen consequences' the authors show how the constellations of interests of the main social actors in Polish courts leads to far-from-optimal effects. Inside the system, judges, court staff, lawyers, defendants and others fall into the trap of unforeseen consequences. At the same time, from the macro-social perspective, the effects imply increasing fragmentation of society, instead of cohesion, for increasing which the whole judicial system is constructed.

Key-words: unforeseen consequences, incarceration, imprisonment rate, Polish justice system, restorative justice

\section{Introduction}

Penal policy is primarily perceived as part of state policy and therefore should meet the goals of widely understood 'social good' and social welfare. Considering that one key factor of social welfare is social cohesion, penal policy should limit its own impact on social fragmentation and remain open to any opportunities to restore social cohesion as far as possible.1 Penal policy is distant from the domain of market economy and seems not to be affected by the phenomena which liberal economists refer to as the invisible hand of the market'. However, on closer examination, the results of the study presented below indicate that in Poland this sphere is strongly influenced by crisscrossing interests of public prosecutors, defendants, courts and court staff.

\footnotetext{
${ }^{1}$ This view was supported by the Polish Senate in 2004 (see Warylewski 2007, 81).
} 
We hypothesise that the judicial system in Poland is characterised by a clash of interests which produces unforeseen effects: contrary to the nominal goals of the actors involved, the system generates full prisons, ineffective deterrence and overworked court staff. The principal aim of this study is to shed some light on the consequences of relations between the main actors of the Polish justice system (hereafter PJS).

Before we focus on the results of our empirical study, we present theoretical inspirations mentioned in the introduction as well as the methodological basis. The discussion of the results is divided into two sections devoted to custodial and non-custodial sentences, respectively.

Penal policy is primarily perceived as part of state policy and therefore should meet the goals of widely understood 'social good' and social welfare. However, on closer examination, the results of the study presented below indicate that in Poland this sphere is strongly influenced by crisscrossing interests of public prosecutors, defendants, courts and court staff.

We hypothesise that the judicial system in Poland is characterised by a clash of interests which produces unforeseen effects: contrary to the nominal goals of the actors involved, the system generates full prisons, ineffective deterrence and overworked court staff. The principal aim of this study is to shed some light on the consequences of relations between the main actors of the Polish justice system (hereafter PJS).

Before we focus on the results of our empirical study, we present theoretical inspirations mentioned in the introduction as well as the methodological basis The discussion of the results is divided into two sections devoted to custodial and non-custodial sentences, respectively.

\section{The Polish judicial system as a field of a play of interests}

Looking for an adequate language to describe the social circumstances outlined above, we can first turn to classical political economy. The invisible hand' is a phrase usually associated with the father of modern economics Adam Smith (2007 [1776]). Although he used this term only three times, it is commonly associated with his main idea that individuals' efforts to pursue their own interests are frequently more beneficial to the community than if their actions were directly intended to further public interest. Smith assumed that a balance between supply and demand is beneficial for economy and society, and that striving to achieve it stimulates economic growth. In his perspective, economy guided by the 'invisible hand' will best meet the needs and interests of the community in general. 
As interpreted by Paul Samuelson (1948), the market will settle on product (service) distribution and prices (costs) that are beneficial to all individual members of a community (i.e. providers and users). However, Smith's idea is therefore limited to a well-functioning market (and not society as a whole), which also requires an external regulatory framework (e.g. moral sentiments). However, the concept of the 'invisible hand' is nearly always generalised beyond Smith's original uses. The idea of market exchange automatically guiding self-interest towards socially desirable ends is a central justification for the neoclassical approach. This approach assumes that markets tend to equilibrium and the actors involved have full and symmetrical access to information.

Such axioms of neoclassical economics have been widely criticised in sociology (Boudon 1982, Tittenbrun 2011) and heterodox streams of economics (Keen 2011). Also mainstream economics provides arguments against the simplified treatment of Smith's proposals. For example, neoinstitutional economics points out that the actors of economic life are diverse, they employ bounded rationality (Simon 1991) and have limited access to information (asymmetric information). Consequently, their actions often miss the optimal solution and lead to unexpected or unwanted external effects. This point of view has also influenced sociology. In this study we examine in detail one of the types of Raymond Boudon's (1982) reversal effects. Drawing on Merton's (1936) unexpected consequences, the French author emphasises that in a heterogeneous, modern society aggregate effects of individual actions often lead to unplanned, unforeseen results. One example is the subjects' rational behaviour leading to effects that are unwanted for the subject (another type is aggregation effects of actions pursued by others).

In this article, we focus not only on relations within the PJS, including those between public prosecutors, defendants, courts and court staff, but also on more general results of the diagnosed state of affairs. Indeed, it produces results which are closer to reversal effects (Boudon 1982), as they are rational only from the point of view of influential actors in individual criminal cases. This situation perpetuates solutions which are ineffective from the point of view of the goals of the PJS as a whole on one hand, and public interest on the other.

In his Making Globalization Work, Joseph E. Stiglitz (2006) observes that 'the reason that the invisible hand often seems invisible is that it is often not there'. What Stiglitz refers to in particular is the problem of economic externalities which represent the impact of a bilateral transaction on uninvolved actors. In other words, externalities are costs or benefits incurred 
by entities that do not participate in the transaction. In this case, the actor outside the transaction is society as a whole. Individual actors within the PJS also suffer damage as a result of the aggregation of individual rational strategies in synergistic effects. Among those suffering actors we can indicate mostly its 'users' - not only those convicted of a crime, but also their relatives (children) and, indirectly, their social environment. Last but not least, the group also includes victims of crimes, who can rarely receive any satisfactory compensation in PJS.

Although the area we studied is not related to the market as such, these observations give us an interesting point of reference for the interpretation of our results. As we present below, decisions which are rational at the level of individual cases in PJS result in crowded prisons, high rate of custodial sentences, and heavy workload of court staff (Warylewski 2007, 80-85). Therefore, we can observe here how actors who have a certain margin of freedom (Crozier and Friedberg 1980) produce reversal effects. On the one hand, their actions generate negative externalities at the level of the system as a whole. On the other, at the level of the agent (within the PJS), individual actors also suffer reverse effects of their own actions. In brief, we approach the PJS as a case of reversal effects that generate external effects (outside the system) and undesirable results inside the system. Although they are theoretically possible to separate, we treat both phenomena as two sides of the same coin.

\subsection{Penal policy in Poland as a factor of social fragmentation}

Between the beginning of transformation in 1989 and 2003 the number of crimes in Poland tripled (Warylewski 2014, 335-336) and crime detection rates increased (from 55\% to 67\%) (Warylewski 2014, 342). As a result, the number of cases handled by criminal courts almost tripled. Between 1989 and 2013 the number of convicted offenders serving a custodial sentence rose from forty to about eighty-five thousand (Warylewski 2014, 344). At the same time, the population of the country declined and the demographic cohorts of young men (aged 15-19 in 2011, thus 20-24 in 2016), who traditionally most often tend to become involved in petty crimes, were definitely less numerous in 2011 (approx. 1.13 million) than ten years earlier (approx. 1.6 million) (Central Statistical Office of Poland 2012).

Wacquant (2009) observes that the policy of incarceration is a result of efforts initiated by some city mayors (e.g. Rudolph Giuliani), politicians and influential think tanks, and has at least two types: an open policy of increasing prison capacity (e.g. in the US, the UK under Blair) and a less transparent policy of different practices (as in France). In his opinion, both of them 
ultimately have the same goal - to isolate and incarcerate those who do not fit in the neo-liberal vision of society (Wacquant 2009, 19-27; see also Bauman 2005), one which believes that, in the words of Margaret Thatcher, 'There is no such thing as society. There are individual men and women, and there are families' (Thatcher 1987). Michał Kozłowski, the Polish translator of Wacquant's (2009) study, rightly observes that the mechanism of legal exclusion is essentially transpolitical. More restrictive provisions of the criminal code and a corresponding penal policy introduced by the coalition government of Law and Justice, the League of Polish Families and Self-Defence (coalition of PiS, LPR and Samoobrona in 2005-2007) were among the very few changes which were not reversed under the Civic Platform and the Polish Peasant Party (coalition of PO, PSL in 2007-2015) (Kozłowski 2009, 13).

In public (especially media) discourse, increasing penalties is perceived as the main deterrent against crime. Such an approach is both outdated and inconsistent with reality. New penal regulations have often been implemented in reaction to shocking incidents that received broad media coverage, such as the murder of the police officer Andrzej Struj in the course of his intervention in a street fight (Wrzosek 2014). Hasty changes mostly consist in increasing maximum prison sentences for particular criminal offences. Adopted by many Polish politicians, this approach results from a stereotypical conviction that increased penalties (i.e. custodial rather than non-custodial sentences, perceived as 'less rigorous' or 'less punitive') have a strong impact on reducing crime figures. In fact, however, this correlation is uncertain and can only be observed with regard to certain types of crimes and offenders, mostly the heaviest. In the case of sentencing policy and the execution of penalties in Poland, the 'unexpected consequences' mechanism produces results which are rational only from the point of view of the more influential actors in individual criminal cases. Indeed, criminal proceedings can be approached in terms of a peculiar game, similar to the interplay of market forces. Here, the most important players are those actors who are the most influential and have the most status and power - the counsel for the defence, trial judges and public prosecutors. The weaker ones include the defendants, probation officers, judges sitting in the enforcement divisions and penitentiary courts, the third sector, and, last but not least, the victims of offences.

We explain this in more detail below, but here we can emphasise that this game of crisscrossing interests promotes solutions which are ineffective from the point of view of the goals of penal policy and the interests of some actors within the system. In spite of the effort of individual members of court staff who aim to reduce the amount of work they have to perform, the system of 
execution of penalties not only generates high economic and social costs, but also, in the long run, increases their workload. The principal aim of the court is obviously to administer justice and execute sentences. However, what becomes apparent in the absence of a stable and uniform penal policy is professional and institutional interests of the parties to the proceedings and other subjects involved.

The result - a high rate of incarceration and the overcrowding of prisons misses not only the whole society's interest, but also the intentions of penal policy-makers (Szymanowski and Migdał 2012, 442-443). Punishment should obviously reflect the social consequences of the act. This, however, does not mean that incarceration is the only available answer (Zalewski 2006, 204-205). Although isolation certainly has its functions, such as prevention, its final outcome involves all the positive and negative (including those unforeseen) impacts on the prisoner during this time (Warylewski 2006, 22). This certainly does not mean that we intend to question the substantive or procedural correctness of criminal judgments. Rather, the problem concerns utilitarian consequences stemming from court decisions and from the practice of their implementation or, to be more precise, from unexpected consequences and perverse effects of adopted solutions, some of which are presented below.

\subsection{Penal policy in Poland as a factor of social fragmentation}

Between the beginning of transformation in 1989 and 2003 the number of crimes in Poland tripled (Warylewski 2014, 335-336) and crime detection rates increased (from 55\% to 67\%) (Warylewski 2014, 342). As a result, the number of cases handled by criminal courts almost tripled. Between 1989 and 2013 the number of convicted offenders serving a custodial sentence rose from forty to about eighty-five thousand (Warylewski 2014, 344). At the same time, the population of the country declined and the demographic cohorts of young men (aged 15-19 in 2011, thus 20-24 in 2016), who traditionally most often tend to become involved in petty crimes, were definitely less numerous in 2011 (approx. 1.13 million) than ten years earlier (approx. 1.6 million) (Central Statistical Office of Poland 2012).

Wacquant (2009) observes that the policy of incarceration is a result of efforts initiated by some city mayors (e.g. Rudolph Giuliani), politicians and influential think tanks, and has at least two types: an open policy of increasing prison capacity (e.g. in the US, the UK under Blair) and a less transparent policy of different practices (as in France). In his opinion, both of them ultimately have the same goal - to isolate and incarcerate those who do not fit in the neo-liberal vision of society (Wacquant 2009, 19-27; see also 
Bauman 2005), one which believes that, in the words of Margaret Thatcher, 'There is no such thing as society. There are individual men and women, and there are families' (Thatcher 1987). Michał Kozłowski, the Polish translator of Wacquant's (2009) study, rightly observes that the mechanism of legal exclusion is essentially transpolitical. More restrictive provisions of the criminal code and a corresponding penal policy introduced by the coalition government of Law and Justice, the League of Polish Families and Self-Defence (coalition of PiS, LPR and Samoobrona in 2005-2007) were among the very few changes which were not reversed under the Civic Platform and the Polish Peasant Party (coalition of PO, PSL in 2007-2015) (Kozłowski 2009, 13).

In public (especially media) discourse, increasing penalties is perceived as the main deterrent against crime. Such an approach is both outdated and inconsistent with reality. New penal regulations have often been implemented in reaction to shocking incidents that received broad media coverage, such as the murder of the police officer Andrzej Struj in the course of his intervention in a street fight (Wrzosek 2014). Hasty changes mostly consist in increasing maximum prison sentences for particular criminal offences. Adopted by many Polish politicians, this approach results from a stereotypical conviction that increased penalties (i.e. custodial rather than non-custodial sentences, perceived as 'less rigorous' or 'less punitive') have a strong impact on reducing crime figures. In fact, however, this correlation is uncertain and can only be observed with regard to certain types of crimes and offenders, mostly the heaviest. In the case of sentencing policy and the execution of penalties in Poland, the 'unexpected consequences' mechanism produces results which are rational only from the point of view of the more influential actors in individual criminal cases. Indeed, criminal proceedings can be approached in terms of a peculiar game, similar to the interplay of market forces. Here, the most important players are those actors who are the most influential and have the most status and power - the counsel for the defence, trial judges and public prosecutors. The weaker ones include the defendants, probation officers, judges sitting in the enforcement divisions and penitentiary courts, the third sector, and, last but not least, the victims of offences.

We explain this in more detail below, but here we can emphasise that this game of crisscrossing interests promotes solutions which are ineffective from the point of view of the goals of penal policy and the interests of some actors within the system. In spite of the effort of individual members of court staff who aim to reduce the amount of work they have to perform, the system of execution of penalties not only generates high economic and social costs, but also, in the long run, increases their workload. The principal aim of the court 
is obviously to administer justice and execute sentences. However, what becomes apparent in the absence of a stable and uniform penal policy is professional and institutional interests of the parties to the proceedings and other subjects involved.

The result - a high rate of incarceration and the overcrowding of prisons misses not only the whole society's interest, but also the intentions of penal policy-makers (Szymanowski and Migdał 2012, 442-443). Punishment should obviously reflect the social consequences of the act. This, however, does not mean that incarceration is the only available answer (Zalewski 2006, 204-205). Although isolation certainly has its functions, such as prevention, its final outcome involves all the positive and negative (including those unforeseen) impacts on the prisoner during this time (Warylewski 2006, 22). This certainly does not mean that we intend to question the substantive or procedural correctness of criminal judgments. Rather, the problem concerns utilitarian consequences stemming from court decisions and from the practice of their implementation or, to be more precise, from unexpected consequences and perverse effects of adopted solutions, some of which are presented below.

\section{Methodology of the study}

The results presented here are the effect of observations made during the evaluation of Restorative Justice Centres in Poland (in polish: Centra Sprawiedliwości Naprawczej). The study itself was focused on practical implementation of restorative justice in cooperation with central and local government. As established in the course of the study, the interplay between the intersecting interests of the main actors of the PJS produces a particular state of balance which, however, involves unforeseen consequences (in Mertonian sense of the term) for the actors of the system and society as a whole. The intersecting interests of these actors shape a certain game between them (Crozier and Friedberg 1980), one that enables them to meet their ambitions, but at the same time generates externalities for the system and the actors themselves. The main objective of this study was to examine the results of the above mentioned research for the presence of unforeseen consequences.

We have identified four key actors of the PJS and their motivations (obviously simplified for the sake of the integrity of the article); these actors are involved in the Restorative Justice Centres presented below and (indirectly) create their outcomes: 
- Defendants and defence: try to avoid penalty altogether or receive the least severe punishment possible,

- Public prosecutors: wish to avoid accusations of leniency and demonstrate effectiveness (a high proportion of secured convictions and, preferably, prison sentences),

- Juries/courts: prefer safe convictions which would stand if appealed, and avoid sentences which might be perceived as unduly lenient,

- Court staff: want to efficiently manage courts and execute sentences (low effort, high efficiency).

The research concerned petty offences and less serious criminal offences, which form the majority of cases handled by Polish courts2. The study involved twenty-four in-depth interviews conducted in three regional court jurisdictions:

- Toruń (T) and Białystok (B), which have their Restorative Justice Centres

- a region referred to as (D); a large city without a Restorative Justice Centre

- In addition, other research methods have been applied:

- focus group interview,

- standardised interview,

- official records search query.

Although focused on the centres themselves, the research also provided extensive information concerning practical problems and dilemmas of the PJS.

\footnotetext{
${ }^{2}$ The study was part of the project entitled 'Pilot implementation of the "Community Court" model in Poland as an institutional bridge between the judiciary, the local and regional government, and community organisations that facilitates practical implementation of restorative justice', which was jointly implemented by the Nicolaus Copernicus University in Toruń, the University of Białystok, the University of Gdańsk and the Court Watch Poland Foundation. The study was financed by the National Centre for Research and Development in Warsaw, Poland, Contract No. IS-1/039/NCBiR/2014.
} 


\section{Custodial sentences as the inescapable heritage of the twentieth century}

Courts make extensive use of provisions which enable them to grant motions for voluntary submission to penalty. In 2014 penalties other than imprisonment amounted only to about $36 \%$ of the total (fines - 24\%, restriction of liberty3 $-12 \%)$. In cases involving medium offences, the most frequent result is a suspended prison sentence. Although the remaining 64\% of penalties were custodial sentences, the restrictiveness of courts was in fact only superficial, considering that $51 \%$ of the total were suspended and carried an actual risk only in the case of repeat offenders. Immediate custodial sentences amounted only to 13\% (Mieszkowska and Orowiecka 2016,14).

When faced with a choice of seeking a fine, restriction of liberty or a suspended prison sentence, public prosecutors choose the last of these options. The level of trust in the deterrent value and the actual execution of the first two penalties is lower than in the case of suspended prison sentences. As estimated by members of probation staff interviewed in this study, only about $20 \%$ of court fines are actually paid. In fact, the proportion is negligible considering that the entire figure represents payments made by offenders afraid of losing their creditworthiness (as they might appear on the register of debtors), and those willing to close their cases and recover their psychological well-being. The situation is similar when it comes to restriction of liberty. In 2003 in Poland, almost half of the offenders failed to perform their community service sentence and provided some kind of excuses (Zagórski 2003,133). On average, considering only those cases in which such punishment was served in some proportion at all, the number of completed hours was a quarter shorter than ordered by courts (Zagórski 2003, 145). Such indicators lead Polish courts to the presumption that the restriction of liberty is a very ineffective penal instrument. In fact, there is no effective mechanism to supervise offenders or assess which of them are ready to fulfil their obligations imposed by this type of punishment. If only a part of expenditures per prisoner was spent on such an mechanism, the outcomes would be better.

The popularity of suspended prison sentences is based on the assumption made by prosecutors and judges that fear of prison is a better tool of resocialisation than any other 'less severe' penalty. In fact, the situation stems from the established routine of prosecution service: public prosecutors want to avoid accusations of leniency and thus find it difficult not to seek a custodial

\footnotetext{
${ }^{3}$ Most often community service.
} 
sentence. Their offer to the defendant most often involves a suspended prison sentence rather than a different form of punishment, classified as more lenient, but at the same time unavoidable (e.g. restriction of liberty, such as community service). This has been the case particularly since the introduction of 'voluntary submission to penalty', which obliges the court to mitigate punishment. On the other hand, prosecutors are not inclined to agree to less severe punishment than a prison sentence.

New regulations introduced a few years ago make it possible for the offenders to voluntarily submit to penalty negotiated with the prosecutor. (...) the only option acceptable to the prosecutor is a prison sentence. Not a fine, not restriction of liberty; it has to be a prison sentence, even if it's suspended. [a judge of regional court: D (JRCD)]

The most frequent form of mitigating a custodial penalty is its suspension rather than imposing punishment of a different type (e.g. restriction of liberty). However, in the subjective perception of offenders, receiving a suspended prison sentence is almost as good as an acquittal.

In practical terms, if custodial sentences are not activated (as a result of reoffending) the offenders do not suffer any penal consequences of their acts. Nor are they subjected to any social reintegration programme, with the exception of some redress to the victim in the course of plea bargaining, when the suspension is at stake. In this way, a prison sentence in practice turns out to be less severe than a heavy fine or community service.

Restriction of liberty is a much more severe punishment because you actually have to do something [community service]; if it's a fine, you have to pay it. And a suspended prison sentence $-90 \%$ of offenders who receive it practically treat it as an acquittal. [JRCD]

In general, courts tend to pass suspended custodial sentences sought by the prosecution, considering that if the accused and the victim agree to the proposal there are generally no grounds to reject it. Also, as generally perceived by court staff, such decisions reduce the heavy workload of the courts.

In a simple case, the court can open the trial regardless of plea bargaining. But some cases involve twenty or thirty witnesses and several defendants, so it's rational that the court approves the settlement. When the prosecutor seeks such a penalty [a suspended custodial sentence] and the defendant pleads guilty and doesn't contest the suspended prison sentence why shouldn't the court approve 
this? The alternative means a trial which might take half a year and can conclude with exactly the same sentence as the one initially proposed by the prosecutor and the defendant. As a result, courts most often grant such motions. [JRCD]

Accepting the thesis of rationality of actors, we can say that in terms of professional satisfaction, public prosecutors are content with a considerable proportion of their motions for conviction without trial being granted, judges - with cases being smoothly decided, and counsels for the defence - with the minimum severity of punishment. In addition, the former two improve their efficiency statistics, and privately appointed counsels receive their fees. All this can be achieved thanks to the quasi-optimal solution, whereby the defendant plea-bargains his case with a view to receiving the least severe punishment possible and, often much to his or her relief, the court passes a suspended custodial sentence.

Even assuming that all parties act in good faith and that professional lawyers perform their duties for the benefit of their clients or public interest as they perceive it, the result is a large number of suspended custodial sentences which are often activated. As we will see below, this, in turn, leads to an increasing prison population and generates high social costs: opportunist attitude to law (as result of treating suspended sentences in terms of 'a pardon'), high rate of return to crime, reintegration of former inmates, broken families, etc. The result involves undesirable social effects excessive incarceration and barriers to institutionalisation, efficiency and effectiveness of non-custodial penalties. We can say that the PJS needs a further optimisation of the contract (better adapted countermeasures) and control (which does not imply a greater administrative control but rather a search for equilibrium between political oversight and the autonomy of the system).

As we mentioned above, one could expect that frequent use of the procedure described above would lead to a decline in the rate of incarceration. In fact, the figures indicate the opposite tendency. Polish prisons have been filled to almost a hundred per cent of their capacity for a decade. Poland has a high rate of incarceration: 193 per 100,000 of population in 2018, the highest in the European Union, except the Baltic States and the Czech Republic (Prionstudies 2018). 
31 | RSC Volume 11, Issue 1, January 2019

Table 1: Prison population rate in 2018 (top 20 jurisdictions in Europe)

\begin{tabular}{|c|c|c|}
\hline Ranking & Title & Prison Population Rate \\
\hline 1 & Russian Federation & 397 \\
\hline 2 & Belarus & 364 \\
\hline 3 & Turkey & 288 \\
\hline 4 & Georgia & 268 \\
\hline 5 & Azerbaijan & 235 \\
\hline 5 & Lithuania & 235 \\
\hline 7 & Moldova (Republic of) & 212 \\
\hline 8 & Czech Republic & 205 \\
\hline 9 & Latvia & 195 \\
\hline 9 & Estonia & 195 \\
\hline 11 & Poland & 193 \\
\hline 12 & Slovakia & 192 \\
\hline 13 & Albania & 188 \\
\hline 14 & Montenegro & 180 \\
\hline 15 & Hungary & 173 \\
\hline 16 & $\begin{array}{ll}\text { Guernsey } & \text { (United } \\
\text { Kingdom) } & \end{array}$ & 165 \\
\hline 16 & $\begin{array}{l}\text { Gibraltar } \quad \text { (United } \\
\text { Kingdom) }\end{array}$ & 165 \\
\hline
\end{tabular}




\begin{tabular}{|l|l|l|}
\hline 18 & Ukraine & 156 \\
\hline 19 & Serbia & 154 \\
\hline 20 & $\begin{array}{l}\text { United Kingdom: } \\
\text { Scotland }\end{array}$ & 143 \\
\hline
\end{tabular}

Source: Prisonstudies 2018.

The peak in Poland was recorded in 2006 at the level of 235 (only Latvia and Lithuania had higher rate that year); in 1989 it was only 106 (Warylewski 2014, 345-346).

The figures show that the conviction that suspended custodial sentences serve as a deterrent is illusory (as we stress below, about $60 \%$ of prisoners serve a sentence which was originally suspended). In fact, what one can identify here is as an 'unforeseen result' or undesirable effect: the efforts of officers of the court and court staff to reduce the number of offenders serving time bring opposite results: in the long run, prison population kept increasing until recent years (when it began to decline as a result of the demographic situation and migration).

A number of studies (Machel 2006; Villettaz, Killias and Soder 2006; Zalewski 2006; Warylewski 2006; Christie 1993) postulate that custodial sentences should be avoided in cases involving minor and medium offences not even because they are 'too oppressive', but because of their high financial and social costs. The monthly cost of maintaining prisons in Poland amounts to about 3,278 złotys (over 750 euros, data for 2017) per prisoner (Ministry of Justice of the Republic of Poland 2017). Moreover, in most cases readaptation of former inmates to life in society is hardly successful. Taking those sentenced away from their families and social environment and putting them in isolated prisons limits their chances of social reintegration, when they are released.

In each individual case, imprisonment involves such social costs as:

- the loss of a source of income by the prisoner's family (dependent relatives, e.g. elderly parents) and a rapidly growing risk of poverty if he or she had a job or another source of income or would be able to get one in the future;

- the loss of the prisoner's social networks; except the most hardened criminals, members of organised criminal groups, or those suffering from severe addictions, it is assumed that most offenders function in a social environment which provides them with more positive than negative stimuli and gives them economic 
and social opportunities to reinvent their life without crime (Bałandynowicz 2006);

- the social costs of unsuccessful re-adaptation of the former prisoner: crimes committed, a lower sense of security in areas of their operation (ibid. 2006);

- maintaining the antisocial prison subculture and the subculture of former inmates (Miszewski 2016).

The problem is not limited to people with families or those who have reasonably stable employment. In the case of younger offenders, suspension of their sentence often stimulates their opportunist attitude to law. This is why, as probation officers comment, they should serve their penalty as soon as possible, and if an immediate prison sentence is too severe, they should receive non-custodial penalties. As we see it, the system operates under the conditions of low diversity of countermeasures. Even when it is formally possible to adapt penalties to offences, this course of action is unlikely to be taken. The above arguments indicate a general ineffectiveness of both suspended and immediate custodial sentences.

\section{The alternative of 'restorative justice': non-custodial sentences}

Problems with social reintegration of former prisoners are an important argument in support of limiting the proportion of custodial sentences. Indeed, post-penitentiary assistance is a very weak element of the penal system in Poland. During our research the problem has been raised particularly by Prison Service (polish: Służba Więzienna) officers. More generally speaking, the legislator considers former prisoners as people at risk of social exclusion (Mika 2010). Return to crime is largely dependent on the availability of solutions on which former inmates can rely to find their place on the labour market and normally function in society.

(...) there is no efficient system which would provide adequate level of assistance from day one, so that the person, the offender, does not return to the life of crime. (...) I wouldn't put the blame only on the services which deal with these issues; in fact the problem is far more complex. [Regional Probation Officer]

A suspended prison sentence in Poland does not have much in common with real probation. The only actual deterrent is the prospect of going to 
prison (Peisert 2016, 30-31). Apart from this, there is often even no supervision, not to mention other elements of the probation process.

If we understand probation as active involvement of probation staff, we have to say that we don't handle all suspended sentences, but only some of them. There are the so-called 'simple' suspended sentences, when the court has passed a prison sentence and suspended it for a specified trial period; these cases remain with the criminal division, and we are charged with community interviews at the most. All we do is collect information. And we can say that we don't do much about such a case; it remains with the court. So, it can happen that there is probation in terms of a trial period, but it isn't the real thing, so to speak, because there is practically no work done with the offender at all. [RPO]

Another issue concerns the fact that the type of penalty is often unsuitable for the social, professional and personality profile of the offender. The problem lies not in the measure of penalty, but in the lack of proper penal and re-socialisation impact. For example, offenders with steady jobs lose them once convicted, which makes them unable to provide financial compensation to the victims. In this context, it is often recommended that instead of a suspended prison sentence, which has a limited impact on the change of attitude, or immediate prison sentence, which is a severe penalty without a restorative value, such offenders should pay a fine and attend compulsory therapy or awareness-raising courses.

On the basis of his professional experience, the spokesperson for the Regional Inspectorate of Prison Service estimates that between 70\% and 80\% of criminal offences in Poland are committed while drunk, or as a result of alcohol or drug abuse. Regional Probation Officers frequently compared Polish penal policy to that adopted in Britain, which far more extensively relies on the use of non-penal measures:

In Britain, there's a programme for people who committed offences while drunk. (...) the offender sentenced by the court has to complete a course, a kind of therapy (...). For example, in one of such sessions they meet the victim. (...) and it's been found quite effective (...). When a probation officer in Britain finds out that someone has committed a drink-driving offence, they, or the court, send them to such a therapy, such a course, which he or she has to complete. In Poland, we tend to think that increasing penalties will solve the problem. [RPO]

This mechanism, in which offenders persistently commit minor offences under the influence of alcohol as a result of their condition and (as is often the 
case) receive a number of suspended prison sentences, is particularly detrimental not only to the offenders themselves, but also to their social environment. In addition, it is socially ineffective. When, following their return to crime, the court finally decides to pass an immediate prison sentence, the sentences which were previously suspended become activated and the offenders end up serving a relatively long period in custody. On completion of the sentence, their family, social and professional relations are in decay, which makes a return to addiction quite likely.

The effectiveness of court probation service staff working with adults is limited due to their heavy workload. In 2014 there were 3,118 probation officers and 15 thousand unpaid offender managers. As on 1 January, there were 401.4 thousand open probation cases, 267.7 thousand of which were handled by probation officers; they supervised 100.9 thousand offenders, 107.7 thousand restriction of liberty orders and 50.9 thousand other cases (penitentiary, electronic monitoring, etc.). In this way, each court probation officer statistically handled 85.6 cases at the same time (Ministry of Justice of the Republic of Poland 2015).

Another problem concerns excessive procedural requirements at various stages of the probation process, and excessive court procedures in general. They have been designed without taking into account, even theoretically, the amount of time and effort required from court staff not only to fully comply with them, but even to perform them at a minimum acceptable level. In the last ten years, the amount of work required to handle a single case has considerably expanded. Although the number of cases is statistically almost the same, this does not reflect an increase in the administrative and procedural workload. One of the interviewed probation officers commented that the time left for the actual probation work was severely limited. Indeed, it appears that financial resources allocated to probation service are a bare minimum required to fulfil its duties and are far insufficient to perform them effectively. In this context, non-governmental organisations specialised in providing assistance to victims of domestic violence or rehabilitation of substance abusers can offer more. In fact, without the involvement of the third sector the task would be almost impossible.

As a result of insufficient re-socialisation support, a considerable number of offenders who received suspended custodial sentences return to crime. According to current estimates from probation staff, about $60 \%$ of prisoners serve activated suspended sentence. Consequently, prisons are crowded. Also, Szymanowski and Migdał (2014) observe that more than a half of inmates are incarcerated for at least the second time. 
Implemented as a punishment alternative to imprisonment, electronic monitoring can even aggravate the problem of insufficient funding for the development of restorative justice tools. This can lead to increasing the number of 'new poor' (Bauman 2005) excluded from the mainstream of society rather than to their reintegration.

The re-socialisation impact of non-custodial penalties is generally ignored. Although seemingly more lenient, they can play their role if a proper system of supervision is in place. Also, they do not generate additional social and financial costs of reintegration of former prisoners.

The court passing a non-custodial sentence can delegate direct supervision of the offender to probation service or a non-governmental organisation. Above, we identified these actors as weak, with less bargaining power within the system. Below we are going to show why. Although the option to delegate supervision would reduce the amount of work performed by court service and use the potential of the third sector, in practice courts do not often take such decisions. Judges tend not to trust non-governmental organisations. In the view of the courts, the instability of their funding and, consequently, working from project to project, creates the risk of discontinuity of resocialisation or reintegration of particular individuals. This structural barrier prevents the delegation of supervision of offenders sentenced to community service. As a result, such penalties are outnumbered by suspended custodial sentences. On the one hand, members of probation service appointed by the court can guarantee proper reaction in difficult cases, when offenders avoid supervision, return to crime (e.g. domestic violence) or cannot cope with substance abuse. On the other, contact between probation staff and offenders is sporadic and their supervision is practically limited to the carrot and stick approach: rewarding with a favourable report and threatening with the prospect of activating the sentence.

\section{Conclusions}

The excessive proportion of suspended prison sentences reveals a mechanism of social fragmentation as well as social exclusion. The solution which is effective from the point of view of the court, court staff, prosecution, defence and public funds, is also superficially beneficial for the offender. Instead of receiving assistance from the state (or the local community), all he or she receives is the suspension of the sentence, which he or she often treats in terms of 'a pardon'. In fact, however, in the case of persons in danger of social exclusion, this means that the solution of the problem is only postponed 
- if the offender reoffends, the problem, or problems, aggravate and the opportunities and motivation to solve them diminish.

As we have shown above, the conditions for the suspension of the sentence are in fact often violated. As a result, all actors within the system become victims of unforeseen consequences. The defendant is threatened by social exclusion and the lack of real support. Court staff are burdened with work and their effectiveness is questioned. Judges and prosecutors enjoy short-term successes, but ultimately also have to work more. Society as a whole becomes a victim of negative externalities.

In view of these considerations, it might be possible to expand Wacquant's $(2009,39-47)$ conclusions on various types of the policy of incarceration to include another type - the policy of incarceration as an unforeseen and, as far as we can see, unexpected consequence. Importantly, it needs to be noted that in this context 'unforeseen' does not at all mean 'unintended'.

In Poland, the policy of incarceration cannot be declared openly, perhaps because the memory of political prisoners of the communist period is still alive. However, a number of mayors are building up their support also by taking measures which aim to 'clear' their towns and cities of 'unwanted elements', hence increased CCTV surveillance, more municipal police patrols, pushing out poverty (homeless shelters, low-standard council housing) to the outskirts. As argued in the present article, increased incarceration can also be identified as an unforeseen consequence of the interplay between intersecting individual and institutional interests, whereby social interest (reintegration of those socially excluded) is pushed aside.

As described above, the play of interests of the actors involved in the PJS generates results which are far from conducive to social welfare and decrease social cohesion. Owing to its inconsistency, the PJS became open to the play of interests of its actors, which brings various external effects, with a high rate of imprisonment as the most visible (financial costs, overcrowding), and many others less visible (social costs). Unfortunately, the voice of Polish penologists, who call for an effective system of re-socialisation of offenders in the name of rebuilding social cohesion affected by penal policy, has not yet been heard.

\section{References}

Bałandynowicz, Andrzej. 2006. Probacja: Resocjalizacja z udziałem społeczeństwa. Warszawa: Wydawnictwo Prawo i Praktyka Gospodarcza. 
Bauman, Zygmunt. 2005. Work, Consumerism and the New Poor. New York: Open University Press.

Boudon, Raymond. 1982. The Unintended Consequences of Social Action. London: Macmillan.

Christie, Nils. 1993. Crime Control as Industry: Towards Gulags, Western Style. London, New York: Routledge.

Crozier, Michel and Erhard Friedberg. 1980. Actors and Systems: The Politics of Collective Action, trans. Arthur Goldhammer. Chicago: Chicago University Press.

Eisenhardt, Kathleen M. 1989. "Agency Theory: An Assessment and Review." The Academy of Management Review 14 (1): 57-74.

Jensen, Michael C. and William H. Meckling. 1976. "Theory of the Firm: Managerial Behavior, Agency Costs, and Ownership Structure.” Journal of Financial Economics 3: 305-360.

Keen, Steve. 2011. Debunking Economics - Revised and Expanded Edition: The Naked Emperor Dethroned? London: Zed Books.

Kozłowski, Michał. 2009. "Wstęp.” In Więzienia nędzy. Lö̈c Wacquant, 713. Warszawa: Książka i Prasa.

Lasocik, Zbigniew. 2006. "Teoria i praktyka penitencjarna a perspektywy systemu więziennego." In Wykonywanie kary pozbawienia wolności $w$ Polsce, edited by Henryk Machel, 29-40. Gdańsk: Wydawnictwo Uniwersytetu Gdańskiego.

Machel, Henryk. 2014. Sens i bezsens resocjalizacji penitencjarnej-casus polski (studium penitencjarno-pedagogiczne). Kraków: Impuls.

Mauer, Marc. 2001. "The Causes and Consequences of Prison Growth in the United States." Punishment and Society 3: 9-20. 
Merton, Robert K. 1936. "The Unanticipated Consequences of Purposive Social Action." American Sociological Review 1 (6): 894-904.

Mieszkowska, Beata and Karolina Orowiecka. 2016. Statystyka sadowa. Prawomocne skazania osób dorostych 2011-2015. Warszawa: Departament Strategii i Funduszy Europejskich Ministerstwa Sprawiedliwości [Department of Strategy and European Founds, Ministry of Justice].

Mika, Bartosz. 2010. "Kręgi społecznego wykluczenia województwa wielkopolskiego w świetle badań własnych." In Spółdzielnie socjalne: Skuteczny mechanizm walki z wykluczeniem społecznym czy ślepa uliczka?, edited by Jacek Tittenbrun. Poznań: Nakom.

Miszewski, Kamil. 2016. "Kobiety odbywające karę długoterminowego pozbawienia wolności." Przegląd więziennictwa polskiego 91: 69-90.

Peisert, Arkadiusz. 2016. “Centra Sprawiedliwości Naprawczej jako instytucja lokalnej polityki społecznej." Polityka społeczna 5-6: 28-33.

Poland. Central Statistical Office of Poland. 2012. Ludność wedtug ptci, wieku, województw i powiatów. http://stat.gov.pl/obszary-tematyczne/ludnosc/ludnosc/ludnosc-bilansopracowany-w-oparciu-o-wyniki-nsp-2011,1,1.html.

Poland. Ministry of Justice. 2015. Sprawozdanie z działalności kuratorskiej służby sądowej w 2014. Ministry of Justice of the Republic of Poland. https://isws.ms.gov.pl/Data/Files/_public/isws/jednoroczne/2014/spr_zbior _2014/ms-s40-r-2014.pdf.

Poland. Ministry of Justice of the Republic of Poland. 2017. Patryk Jaki. Odpowiedź na zapytanie nr 1952 w sprawie kosztów utrzymania więźnia $w$ skali roku.

http://www.sejm.gov.pl/sejm8.nsf/InterpelacjaTresc.xsp?key=3423FE20

Prisonstudies. 2018. www.prisonstudies.org. Accessed 23.12.2018. 
Samuelson, Paul. 1948. Economics. York: The Maple Press Company. Simon, Herbert A. 1991. "Bounded Rationality and Organizational Learning." Organization Science 2 (1): 125-134.

Smith, Adam. 2007 [1776]. An Inquiry into the Nature and Causes of the Wealth of Nations. Books I, II, III, IV, V. Amsterdam, Lausanne, Melbourne,

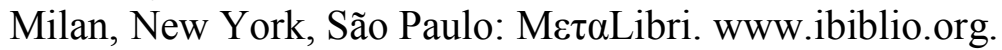

Stiglitz, Joseph E. 2006. Making Globalization Work. New York, London: W.W. Norton \& Company.

Szymanowski, Teodor And Jerzy Migdał 2012. Prawo karne wykonawcze $i$ polityka penitencjarna. Warszawa: Lex.

Tittenbrun, Jacek. 2011. Ownership and social Differentiation, Understandings and Misunderstandings. Lambert Academic Publishing.

Killias Martin, Patricie Villettaz and Isabel Zoder. 2006. The Effects of Custodial vs. Non-Custodial Sentences on Re-Offending: A Systematic Review of the State of Knowledge. The Campbell Collaboration. 2006: 13 https://www.campbellcollaboration.org/media/k2/attachments/Killias_Se ntencing_review_corrected.pdf.

Wacquant, Loïc. 2009. Prisons of Poverty. Minnesota: Minnesota University Press. Polish edition: Loïc Wacquant. 2009. Więzienia nędzy, trans. by Michał Kozłowski. Warszawa: Książka I Prasa.

Warylewski, Jarosław. 2006. "O wybranych funkcjach i celach kary pozbawienia wolności." In Wykonywanie kary pozbawienia wolności w Polsce, edited by Henryk Machel, 19 - 28. Gdańsk: Wydawnictwo Uniwersytetu Gdańskiego.

Warylewski, Jarosław. 2007. Kara. Podstawy filozoficzne i historyczne. Gdańsk: Wydawnictwo Uniwersytetu Gdańskiego.

Warylewski, Jarosław. 2014. "Wymiar sprawiedliwości karnej w Polsce: diagnoza statystyczno-kryminologiczna wybranych aspektów." In Między naukq a praktykq prawa karnego. Księga Jubileuszowa Profesora Lecha 
Gardockiego, edited by Zbigniew Jędrzejewski et. al., 335-346. Warszawa: C.H. Beck.

Wrzosek, Marta. 2014. Zaostrzenie kodeksu karnego. INFOR. http://www.infor.pl/prawo/prawo-karne/aktualnosci/221333,Zaostrzeniekodeksu-karnego.html.

Zagórski, Janusz. 2003. Orzekanie i wykonywanie kary ograniczenia wolności oraz pracy społecznie użytecznej $w$ Polsce $w$ świetle analizy przepisów $i$ wyników badań. Warszawa: Biuro Rzecznika Praw Obywatelskich.

Zalewski, Wojciech. 2006. "Mass imprisonment - koniec marzeń o alternatywie dla kary pozbawienia wolności?." In Wykonywanie kary pozbawienia wolności $w$ Polsce - $w$ poszukiwaniu skuteczności. edited by Henryk Machel, 197-206. Gdańsk: Wydawnictwo Uniwersytetu Gdańskiego.

Zalewski Wojciech and Andrea Părosanu. 2015. "Poland." In European Research on Restorative Juvenile Justice, vol. 1, Research and Selection of the Most Effective Juvenile Restorative Justice Practices in Europe: Snapshots from 28 EU Member States, edited by Frieder Dünkel, Philip Horsfield and Andrea Părosanu. Brussels: International Juvenile Justice Observatory, 131135.

http://www.euforumrj.org/wp-content/uploads/2015/06/Vol-1.-EUResearch-IJJO.pdf. 